\title{
The Cixiidae (Hemiptera: Fulgoromorpha) of the Mascarenes islands and Madagascar. Endemism and description of new taxa from Réunion with notes on their host plants
}

\author{
Marc ATTIÉ 1 Thierry BOURGOIN² and JACQUeS BONFILS $S^{3}$ \\ ${ }^{1}$ CIRAD 3P, 7 chemin de 1'IRAT, F-97410 Saint-Pierre, France; e-mail: attie@cirad.fr \\ ${ }^{2}$ Muséum National d'Histoire Naturelle, Laboratoire d'Entomologie \& ESA 8043 CNRS, 45 rue Buffon, F-75005, Paris, France; \\ e-mail: bourgoin@mnhn.fr \\ ${ }^{3} 10$, rue des Bouvreuils, F-81200 Aiguefonde, France
}

Key words. Hemiptera, Fulgoromorpha, Cixiidae, Eumyndus, Achaemenes, Aselgeoides, Brixia, Oliarus, Cubana, Borbonomyndus gen. n., Meenocixius gen. n., Achaebana gen. n., new species, endemism, host-plant, Arecaceae, Pandanaceae, La Réunion, Rodrigues, Madagascar

\begin{abstract}
Two new species (Hemiptera, Fulgoromorpha, Cixiidae) included in a new genus, Meenocixius gen. n., and associated with Acanthophenix rubra (Bory) H. Wendl. (Arecaceae) are described from the island of La Réunion: $M$. bebourensis $\mathrm{sp} . \mathrm{n}$. and $M$. virescens sp. $\mathrm{n}$. This genus shows several autapomorphies in its tegmina venation, very particular within the Fulgoromorpha. Borbonomyndus gen. n., is proposed for another new species, B. pandanicola sp. n. associated with Pandanus purpurascens Thouars (Pandanaceae), and B. pallidus (Synave), previously described as a member of the genus Eumyndus Synave. According to morphological and ethological data, E. bistriatus is synonymized with $B$. pallidus, of which three different forms are recognized. All species of Borbonomyndus are found associated with Pandanus. These two new genera are endemic to La Réunion. Without taxonomic standing, the subspecies of Brixia belouvensis are synonymyzed and restricted to four different forms. A key is proposed for the Cixiidae of La Réunion, which now includes 12 species belonging to 6 different genera: Achaemenes, Aselgeoides, Brixia, Oliarus (but we show that the species placed in this genus need to be reviewed), Borbonomyndus, and Meenocixius. Monophyly of Eumyn$d u s$, from which $E$. perinetensis Synave is excluded, is substantiated. Following the new interpretation, this genus is now restricted to Madagascar. The species Cubana insularis Muir, from the island of Rodrigues, is transferred to a new genus: Achaebana gen. $\mathrm{n}$. Finally, cixiid endemism and their host-plant associations in the Mascarenes are discussed.
\end{abstract}

\section{INTRODUCTION}

Almost all species of Cixiidae in the Mascarene islands are endemic and associated with native vegetation (Williams, 1975a; Attié et al., 1998) and particularly endemic plants (Attié, 1999). In Mauritius, the 35 species and subspecies belong to three genera (Achaemenes Stål, 1866, Brixia Stål, 1856 and Oliarus Stål, 1862) (Synave, 1960, 1961; Williams, 1975a, 1983; Williams \& Williams, 1988) including 27 species in the genus Brixia, which appears to be the most diversified Mascarene genus (Williams \& Williams, 1988). Rodrigues has the least diversified fauna of the three Mascarene islands of the archipelago with only four species belonging to two genera (Brixia and Cubana Uhler, 1895) (Muir, 1925; Williams, 1983; Williams \& Williams, 1988). The data on the Cixiidae of Madagascar consists mainly of alphataxonomic information on more than 60 species belonging to 7 genera (Synave, 1956, 1965). Furthermore, etho-ecological information is scarce.

The Cixiidae of La Réunion were first studied by Synave (1965) and then by Williams (1975a, b). Their work distinguished ten different species (Williams \& Williams, 1988; Bonfils et al., 1994) belonging to five genera (Achaemenes, Aselgeoides, Brixia, Oliarus and Eumyndus Synave, 1956). Very little etho-ecological data exists, particularly on their host-plants.
In order to analyse the endemism of this insular fauna, particularly in relation to their endemic host-plants, new collections and a taxonomic revision were undertaken, together with a comparison of the cixiid species of the different Mascarene islands and Madagascar. The field work added three new species of Cixiidae to the fauna of La Réunion, which are also described. The taxonomic revision gave us the opportunity to:

1. Redefine the genus Eumyndus, which is now restricted to Madagascar;

2. propose three new endemic genera: Borbonomyndus gen. n. and Meenocixius gen. n. from La Réunion, and Achaebana gen. n. from Rodrigues;

3. to provide new taxonomic information for two other genera present in La Réunion: Oliarus and Brixia. Some new etho-ecological data are provided for most of these taxa and the origin of cixiid endemism discussed.

\section{THE EUMYNDUS GENUS FROM MADAGASCAR}

In 1960, Synave described two cixiid species from Réunion which appeared to be morphologically intermediate between the genus Eumyndus from Madagascar and Volcanalia Distant, 1917, from Seychelles. However, these species were finally placed by Synave in the Malagasian genus Eumyndus. 
A revision of these taxa, together with the description of a new species, allow us to transfer them to a new endemic genus Borbonomyndus gen. n. which also belongs to the Oecleini Muir, 1922. Eumyndus is therefore redefined and compared to a group of three closely related genera distributed in the same geographical area and that lack the transversal carina separating frons from vertex: Volcanalia, Nesomyndus Jacobi, 1917 and Borbonomyndus gen. $\mathrm{n}$.

\section{Eumyndus Synave, 1956}

Type species. Eumyndus madagascariensis Synave, 1956 180

Distribution. Endemic to Madagascar (Fig. 22)

Included species. E. madagascariensis Synave, 1956; E. metcalfi Synave, 1956; E. kraussi Synave, 1956, [excluded: Eumyndus perinetensis Synave, 1965]

The genus is redefined and characterized by the following combination of characters, some of them proposed as autapomorphies (A) for this taxa: Vertex without median carina, its posterior margin absolutely straight (A); posterior margin of the vertex almost twice as wide as anterior margin and wider than the compound eye narrowest diameter. Absence of the mediofrontal carina. Posterior margin of pronotum strongly concave, middle part (between the lateral carinae of the vertex) not visible in dorsal view as hidden under the head capsule. Lateral carinae of the pronotum reach the anteroventral margins in fronto-lateral view but turn dorsad before reaching the level of the compound eyes, then vanish dorsally. Tegminae with $\mathrm{Sc}+\mathrm{R}$ separating before $\mathrm{CuA}$. Epiproct short, anal tube posteroventrally extended in an impair process (A). Periandrium developed only on its left side and ventrally, with the lateral left process curved less or no more than $180^{\circ}$, pointing postero-ventrally. Aedeagus s.s. as a membranous tube situated on the right side.

Taxonomic note. The genus Nesomyndus differs from Eumyndus in having a median carina on the frons and the clypeus, and a narrow hollowed vertex, posteriorly angled and not masking the pronotum medially. The posterior margin of pronotum is strongly concave and still fully visible in dorsal view. In frontal view, a strong straight and oblique anterolateral carina runs orthogonally from the margin of the compound eye and reaches distally the anteroventral margin. Volcanalia is an endemic genus from the Seychelles, which differs from Eumyndus in having strong and wide mediofrontal carinae and in the shape of the thin hollowed vertex (as a furrow) between the compound eyes.

The Malagasian species Eumyndus perinetensis Synave, 1965, is clearly not congeneric with any of these taxa and has to be excluded from the genus Eumyndus. It differs by its frons bearing a delicate median carina and stronger and foliated lateral carinae, by the lateral carinae of the pronotum vanishing ventrally and not reaching the antero-ventral margin, and by the general conformation of the male genitalia, which bear two long processes on each side of the aedeagus. However, with Eumyndus it shares the wider posterior margin of the vertex and in dorsal view the strongly incurved posterior margin of the pro- notum hidden medially by the head capsule. Probably a new genus should be created for this species, but this will have to be checked within a general revision of the cixiid fauna of Madagascar, which is out with the scope of this study.

The male genitalia of $E$. metcalfi differs from that of the type species, with the periandrium strongly developed ventrally and bearing a small spine-like process, a development absent in E. madagascariensis. The male of $E$. kranssi is still unknown.

With this new status E. pallidus becomes non congeneric with the other species and therefore a new genus is proposed.

\section{DESCRIPTION OF NEW TAXA FROM LA RÉUNION ISLAND}

\section{Borbonomyndus gen.nov.}

Type species. Borbonomyndus pandanicola $\mathbf{s p .} \mathbf{n}$.

Distribution. Endemic to La Réunion Island (Fig. 22)

Included species. Borbonomyndus pallidus (Synave, 1960), Borbonomyndus pandanicola sp. $\mathbf{n}$.

Posterior margin of vertex angled, not straight, wider than anterior margin; its length less or just slightly longer than the short diameter of the compound eye; vertex not strongly hollowed but the lateral carinae elevated; no median carina. Frons without mediofrontal carina, lateral carinae in the same plane as the frontal disc, not pointing anteriorly but laterally. Clypeus without medioclypeal carina. Pronotum with posterior margin strongly concave, but still visible in dorsal view, not hidden by the head capsule; in frontal view, lateral pronotal carinae distally reach the anteroventral margins; more dorsally fully visible and S-curved around the eye margin, then vanishing dorsally. Mesonotum with three carinae, the lateral carina diverging posteriorly. Tegminae with $\mathrm{Sc}+\mathrm{R}$ separating basally to $\mathrm{CuA} 1$ and $\mathrm{CuA} 2$. Epiproct long: As long or longer than the dorsal margin of the anal tube in lateral view. Anal tube posteriorly produced on each side of the epiproct forming two more or less developed processes. Lamina gonostyli present and short. Periandrium developed only on the left side and ventrally, forming a wide ring supporting the aedeagus in ventral view. Lateral left process of the periandrium long, thin, running posterodorsad then turning ventrally and anteriorly at almost $360^{\circ}$. Aedeagus as a membranous tube situated on the right side.

\section{Type species. Borbonomyndus pandanicola sp. $\mathbf{n}$.}

Taxonomic note. It is difficult to propose any synapomorphy for the genus moreover without any cladistic analysis. However, the very long lateral process of the periandrium, curved at $360^{\circ}$ might represent a good autapomorphy for the genus. Borbonomyndus is close to Eumyndus by the general conformity of the male genitalia, but the autapomorphic shape of the vertex in the Madagascar genus allows a quick separation.

Borbonomyndus pallidus (Synave, 1960) comb. n.

Eumyndus pallidus Synave, 1960: 138

Eumyndus bistriatus Synave, 1960: 138, syn. n. 
TABLE 1. Tegminal patterns of Borbonomyndus pallidus in relation to its distribution, host-plants and type of genitalia. Tegminal patterns: a: $\delta$-hyaline; b: $\delta$-bi-striped chesnut, b: $d$-bi-striped chesnut very pale; $c$ : $q$-bi-striped dark chesnut; d: $q$-bicoloured; e: $q$-hyaline. Aedeagus type patterns: I: with 4 spines; II: with 3 spines.

\begin{tabular}{|c|c|c|c|c|c|}
\hline Patterns & Genitalia types & Host plants & Localities & Dates & References \\
\hline$d$ & & P. montanus & P. des Fougères $(E)$ & 14.III.1997 & 1400 \\
\hline $\mathrm{a}, \mathrm{c}$ & II & P. purpurascens & P. des Fougères $(E)$ & 14.III.1997 & 1402 \\
\hline $\mathrm{a}, \mathrm{b}, \mathrm{d}$ & & P. purpurascens & $P$. des Fougères $(E)$ & 14.III.1997 & 1403 \\
\hline$a, b, c, d$ & & P. purpurascens & P. des Fougères $(E)$ & 4.II. 2000 & 1667 \\
\hline$a, b, c, d$ & $\begin{array}{l}\text { II, one apical spine feebly } \\
\text { marked }\end{array}$ & P. purpurascens & S. Pointe du Tremblet & 26.III.1997 & 1401 \\
\hline $\mathrm{b}, \mathrm{c}$ & & P. purpurascens & S. Pointe du Tremblet & 26.III.1997 & 1404 \\
\hline $\mathrm{b} \times \mathrm{c}$ & II & P. purpurascens & S. Pointe du Tremblet & 5.XII. 1999 & 1662 \\
\hline$b$ & II & & S. Pointe du Tremblet & & 1663 \\
\hline $\mathrm{a} \times \mathrm{c}$ & II & P. purpurascens & S. Pointe du Tremblet & 5.XII.1999 & 1664 \\
\hline $\mathrm{a}, \mathrm{c}, \mathrm{e}$ & II & P. montanus & P. des Palmistes & 30.X.1997 & 1405 \\
\hline $\mathrm{a}, \mathrm{c}, \mathrm{e}$ & & P. montanus & P. des Palmistes & 30.X.1997 & 1406 \\
\hline $\mathrm{a}, \mathrm{c}, \mathrm{d}$ & I & P. purpurascens & Vallée-Heureuse & 13.I.1998 & 1586 \\
\hline $\mathrm{b}$ & I & & Vallée-Heureuse & & 1586 \\
\hline $\mathrm{c}$ & & P. purpurascens & Mare-Longue & 13.XI.1999 & 1660 \\
\hline$b, d$ & & $P$. purpurascens & Mare-Longue & 13.XI.1999 & 1661 \\
\hline $\mathrm{b} \times \mathrm{c}$ & & P. purpurascens & Mare-Longue & 13.XI.1999 & 1665 \\
\hline$a \times c$ & I & P. montamus & Plaine des Chicots & 7.1.2000 & 1666 \\
\hline
\end{tabular}

In "Le Naturaliste malgache" dated 1959 but published in 1960 (2nd quarter), Synave described two species in the genus Eumyndus: E. pallidus with hyaline tegminae (Fig. 11) and E. bistriatus with bi-striped dark chestnut tegminae (Figs 2, 10). As no male was recorded for $E$. bistriatus and no female mentioned for $E$. pallidus, Synave added that it was possible that $E$. bistriatus may be a form of E. pallidus. According to Williams (1975b), these two species are indistinct and both belong to E. pallidus. Indeed, one of the two females collected by this author is bi-striped as is E. bistriatus, whereas the second had only a trace of pigmentation on the tegminae. Our new collects and field observation of numerous specimens with various tegminal patterns, allow us to present new details and, in agreement with Williams (1975b), to formally synonymyse these two species, and include them in the new genus Borbonomyndus.

Various tegminal patterns were observed (Figs 9-11). Only two of them occur in male specimens: a hyaline pattern (a) corresponding to the description of $E$. pallidus by Synave (1960) and a bi-striped chestnut pattern (b), of variable strength (Figs 1,2). The (b) pattern is similar to the one reported by Synave (1960) for females of $E$. bistriatus. In females, three different patterns were observed: a bi-striped dark chestnut pattern (c) (Fig. 2), similar to $E$. bistriatus, a new bicoloured pattern (d) with the whole of the anterior prenodal part of the tegminae coloured (Figs $3,9)$ and females with hyaline tegminae (e).

The study of the male genitalia of specimens with (a) and (b) tegminal patterns revealed similar structures (Fig.15), except for the genital spinulation. Two types of genitalia were observed: in type I there were four spines (Fig. 17) and in type II three, with one of the apical spines absent (Fig. 16). The genitalia of E. pallidus [form (a)] illustrated by Synave (1960: fig. 6) correspond to type I. Both genital types also occur in individuals with tegminal patterns (a) and (b) (Table 1).

In addition, six couples were collected in copula. Only the most common of the tegminal patterns of were concerned: (a)x(c) and (b)x(c) (Fig. 5). Dissections showed that males of both genital types mated with females with the (c) pattern.

These observations led us to conclude that the two taxa are synonyms as supposed by Synave in 1960 and expected by Williams (1975b). There is, therefore, no reason to maintain $E$. bistriatus and $E$. pallidus as separate species. To facilitate future field researchs three forms are however recognized at the infraspecific level:

Borbonomyndus pallidus (Synave, 1960: 138)

Eumyndus bistriatus Synave, 1960: 138, syn. n.

form pallidus: Hyaline tegminae - males with pattern (a) or females with pattern (e) -

form bistriatus: Bi-striped tegminae - males with pattern (b) or females with pattern (c)

form bicoloratus: Bicoloured tegminae, known only from females with pattern (d).

The various and distinct phenotypic patterns shown by B. pallidus might be considered as a evidence of speciation in progress. This hypothesis still needs to be tested, but its determinism is probably not linked to host-plant speciation. Indeed, all forms of E. pallidus are always associated with only two endemic species of Pandanaceae on La Réunion: Pandanus purpurascens Thouars and $P$. montanus Bory (Table 1).

Another hypothesis is that the different patterns observed are the result of eco-geographical constraints. Indeed, B. pallidus is found in lowland forest (Mare- 


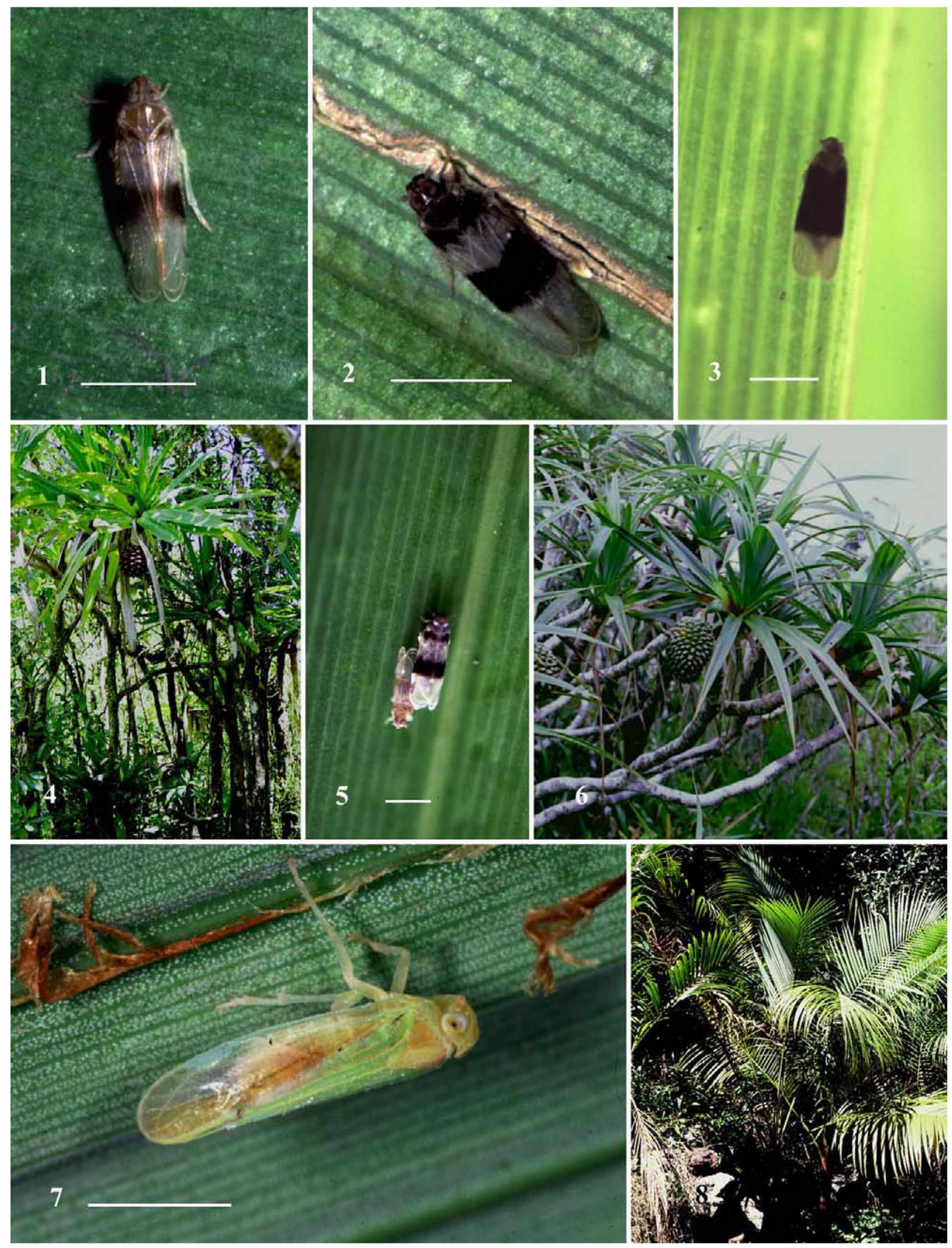

Figs 1-8. 1 - Male of Borbonomyndus pallidus, bi-stiped chesnut tegminae; 2 - Female of B. pallidus, bi-stiped dark chesnut tegminae; 3 - Female of $B$. pallidus, bicoloured patterned tegminae; 4 - Pandanus purpurascens, a host plant of $B$. pallidus and $B$. pandanicola $; 5-B$. pallidus in copula; 6 - Pandanus montanus, a host plant of $B$. pallidus; 7 - Female of Meenocixius virescens; 8 Acanthophenix rubra (Arecaceae), the host plant of $M$. virescens and $M$. bebourensis. (scale: $2 \mathrm{~mm}$ ) 

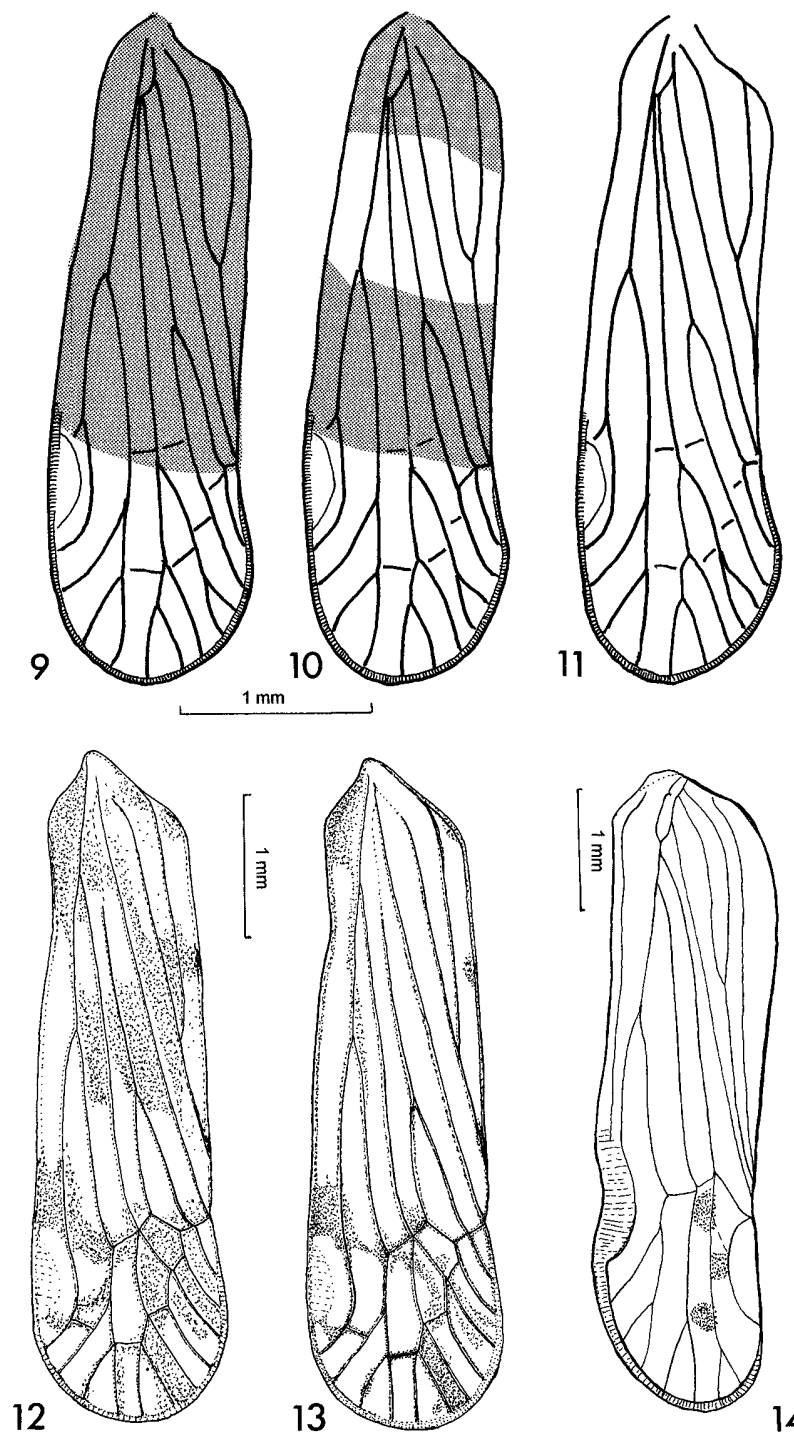

Figs 9-14. Borbonomyndus pallidus (Synave) right tegmina: 9 - form bicoloratus: new bicoloured tegmina pattern in a female; 10 - form bistriatus: bi-striped chestnut tegmina pattern in a female $[=E$. bistriatus sensu Synave $(1960)] ; 11-$ form pallidus: hyaline tegmina pattern $[=E$. pallidus sensu Synave (1960)]; 12, 13 - Borbonomyndus pandanicola sp. n.; 14 - Meenocixius bebourensis $\mathrm{sp} . \mathrm{n}$.

Longue from $470 \mathrm{~m}$ altitude) up to mountain rain forest (1500 m altitude) (Attié, 1999). This area is highly diverse in various biotopes. However, the different patterns seem restricted to rather delimited geographic areas (Fig. 22): The (d) and (b) patterns were only observed in "Plaine des Fougères", in "Sentier de la pointe du Tremblet" and in "Mare-Longue", and the (e) pattern only in "Plaine des Palmistes". Patterns (a) and (c) occur in all areas. The same was so for the male genitalia types as only one type is observed in each area (Table 1). However, these observations do not necessarily support either hypothesis, and perhaps the observed tegminal pattern polymorphism is only the result of the expression of one or more alleles. A further study of the different populations of E. pallidus is now needed.
Material examined. $1 \%$ (d), Plaine des Fougères (Est), 14.III.1997, on Pandanus montanus Bory (Pandanaceae) (Ref. MA 1400, M. Attié rec.); 7 (a), 89 (c), idem on P. purpurascens Thouars (Ref. 1402, M. Attié rec.); $60^{\star}$ (a), $20^{\star}$ ((b) pigmentation not very marked), $5 \circ$ (d), idem (Ref. MA 1403, M.

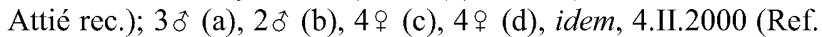
MA 1667, M. Attié rec.); $1 \delta^{\star}$ (a), $14 \delta^{\star}$ (b), 7 ㅇ (c), 1 ㅇ (d), Sentier de la pointe du Tremblet, 26.III.1997 on P. purpurascens (Ref. MA 1401, M. Attié rec.); $2{ }^{\dagger}$ (b), 49 (c), idem (Ref. MA 1404, M. Attié rec.); $7 \delta^{\circ}$ (a), 79 (c), 3 \% (e), Plaine des Palmistes, 30.X.1997, on P. montanus (Ref. MA 1405, M. Attié \& G. Morel rec.); $7 \delta$ (a), $9 \%$ (c) 2 of them are not very marked, $6 \%$ (e), idem (Ref. MA 1406, M. Attié \& G. Morel rec.); 90 (a), 20 (c), 1 ㅇ (d), Vallée-Heureuse, 13.I.1998, on P. purpurascens (Ref. MA 1586, Attié rec.); 19 (c), Mare-Longue (this locality is near Vallée-Heureuse), 13.XI.1999, on P. purpurascens (Ref. MA 1660, G. Morel rec.); 90 (b), 2 ㅇ (d) idem, 5.XII.1999 (Ref. MA 1661, M. Attié rec.); 2 pairs in copula (b)x(c), idem (Ref. MA 1665, M. Attié rec.); 1 pair (b)x(c), Sentier de la Pointe du tremblet, 5.XII.1999, on P. purpurascens (Ref. MA 1662, Attié rec.); 1 pair in copula (b)x(c), idem, (Ref. MA 1663, Attié rec.); 1 pair in copula (a)x(c), idem, (Ref. MA 1664, Attié rec.); 1 pair in copula (b)x(c), idem, (Ref. MA 1665, Attié rec.); 1 pair in copula (a)x(c) sur P. montanus, plaine des Chicots, 7.I.2000, on P. montanus (Ref. 1666, M. Attié rec.).

\section{Borbonomyndus pandanicola sp. $\mathbf{n}$.}

General habitus pale brown with more or less darker and extended spots. Vertex pale brown, with two elongated darker spots on its median anterior part in darker specimens. Frons and clypeus dark brown with an elongated central creamish spot on the frons at the level of the eyes; carina generally paler. The area below the compound eye, around the ocellus and around the antennal base dark brown. Pronotum pale behind the lateral carina, dark anteriorly. Tegulae pale. Mesonotum uniformly pale brown in paler specimens, with two elongated dark bands between the lateral carinae and bordering the tegulae in the dark specimens. Tegminae with a large more or less extended brown spot: A basal costal one, an elongated one between $\mathrm{Sc}+\mathrm{R}$ and $\mathrm{M}$ more or less elongated towards the posterior margin (absent in pale specimens), a band running on the nodal line extending more or less toward the cubital post-nodal area; second external median cell brown (Figs 12, 13).

Male genitalia. Anal tube relatively long, laterally produced into two flatened processes; in lateral view, epiproct as long as the dorsal margin of the anal tube (Fig. 20). Pygofer ventrally produced into a relatively wide rounded medioventral process (Fig. 19) while it is more slender and pointed in B. pallidus (Fig. 18); posterior margin regularly convex, produced into a rounded process medially. Left lateral process of the aedeagus apically with a pair of spines, a subdistal one pointing posteriorly; at mid length one spine pointing posteriorly followed by a double-spined process pointing anteriorly (Fig. 21). In lateral view, aedeagus s.s. reaching posteriorly as far as the lateral left process.

Measurements. Male (5 ex.), total length: 5.31-5.56 $\mathrm{mm}$; tegminae: $4.37-4.69 \mathrm{~mm}$.

Female (10 ex.), total length: $5.44-5.81 \mathrm{~mm}$; tegminae: $4.44-4.94 \mathrm{~mm}$. 

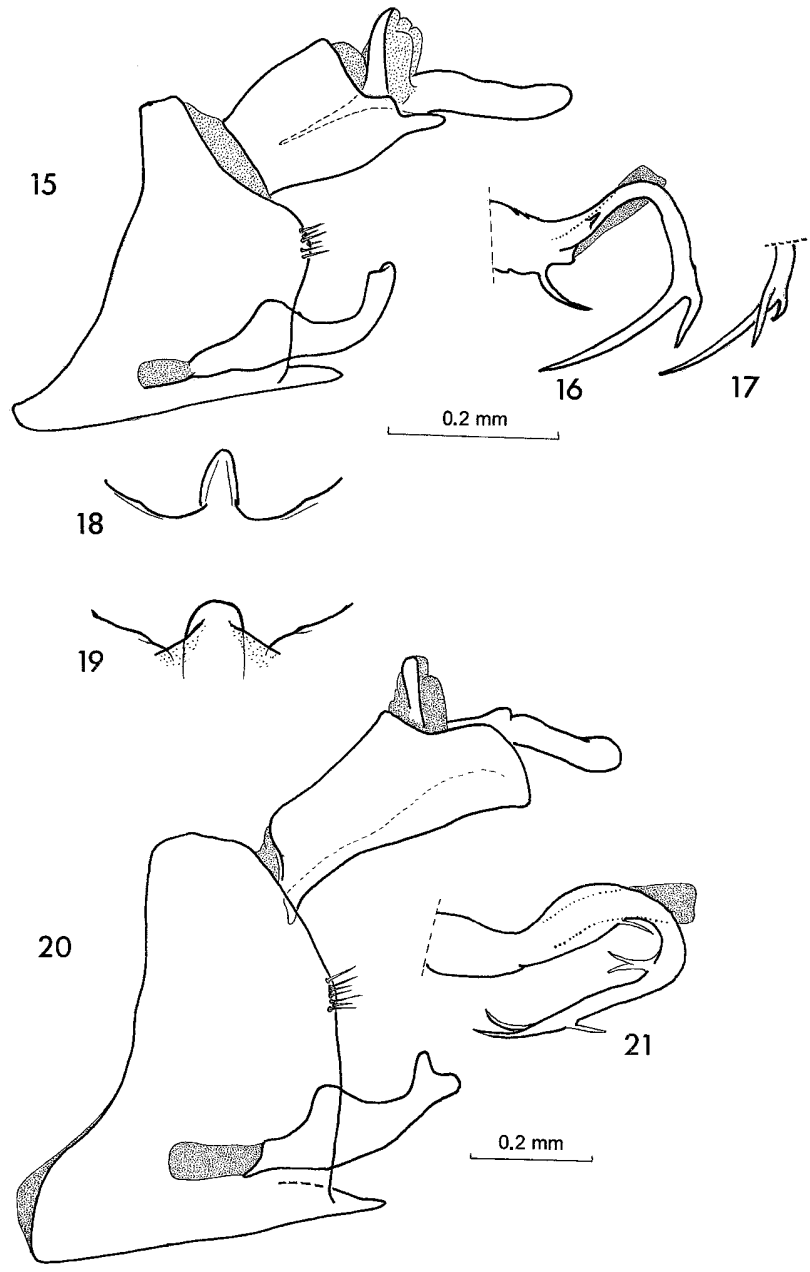

Figs 15-21. Borbonomyndus sp., male genitalia - B. pallidus (Synave): 15 - pygofer, anal tube and gonostyli, lateral view; 16 - aedeagus, type II with only 3 spines; 17 - aedeagus, type I with 4 spines. 18 - medioventral process - B. pandanicola $\mathrm{sp}$. n.: 19 - medioventral process; 20 - pygofer, anal tube and gonostyli, lateral view; 21 - aedeagus.

Distribution. La Réunion (Fig. 22).

Material examined. Holotype male: La Réunion, MA 1650, Mare-Longue, 13.XI.1999, on Pandanus purpurascens (G. Morel rec.), deposited in MNHN.

Paratypes in MNHN: $2 \circ$ same data as holotype; $20,4 ㅇ ㅏ . \mathrm{La}$ Réunion, MA 1653, Mare-Longue, 5.XII.1999, on Pandanus purpurascens (M. Attié rec.).

Other specimens. 2‡, 11으, Mare-Longue, 13.XI.1999, on $P$. purpurascens (Ref. MA 1650, G. Morel rec.); 2‡, 6우, MareLongue, 5.XII.1999 (Ref. MA 1653, M. Attié rec.); 80ิ, 2 ㅇ, Plaine des Fougères, 4.II.2000 (Ref. MA 1668, M. Attié rec.) all in coll. Attié.

Taxonomic and distribution note. $B$. pandanicola is the largest species in the genus, and easily recognisable. It differs from $B$. pallidus in the general shape of the pygofer, a longer anal tube and the shape of the gonostyli (Figs $15,20)$ as well as in the shape of the medioventral process of the pygofer (Figs 18, 19). Like B. pallidus, it also lives on Pandanus purpurascens. Its distribution however, seems much more restricted to the lowland rain forest of "Mare-Longue" (470-500 m altitude), and to the submontane rain forest of "Grand-Étang" $(570 \mathrm{~m})$ and "Plaine des Fougères" (800 to $950 \mathrm{~m})$. Because B. pallidus seems to be a rather polymorphic species, we have selected B. pandanicola as the type species for the genus.

\section{Meenocixius gen. $\mathbf{n}$.}

Type species. Meenocixius bebourensis $\mathrm{sp} . \mathrm{n}$.

Distribution. Endemic to La Réunion Island (Fig. 22)

Included species. Meenocixius bebourensis sp. n., Meenocixius virescens $\mathrm{sp} . \mathrm{n}$.

Vertex quadrangular, wider than long, margins strongly carinated, disk hollowed, median carina absent. Posterior margin obtusely angulate, lateral margins posteriorly regularly diverging, anterior margin straight. Frons with median carina not reaching the vertex; laterofrontal carinae foliated pointing laterad. Postclypeus with a median carina vanishing ventrally, lateral margins vanishing on the anteclypeus. Median ocellus almost absent. Pronotum with disk somewhat quandrangular, anteriorly straight, posteriorly concave and obtusely angulate; lateral carinae not reaching the posterior margin but strongly curved and parallel to posterior margin of the eye, running towards the middle of the lower pronotal margin without reaching it (Fig. 23). Mesonotum with lateral carinae slightly diverging, median carina vanishing posteriorly. Tegminae long, distinctive, with three long anal veins into the clavus, strongly elevated but not foliate; A1 and $\mathrm{A} 2$ fusing in the second third of the clavus, A1+A2 and $\mathrm{A} 3$ fusing at apex; basal part of $\mathrm{A} 1$ and $\mathrm{A} 2$ bearing setae regularly and horizontally spaced on each side of the vein; A3 cell (area posterior to A3) as wide as A2 cell (area posterior to A2) and wider than A1 cell (area between A1 and A2). Proximal part of costal margin convex. $\mathrm{Sc}+\mathrm{R}+\mathrm{M}+\mathrm{Cu}$ basally fused in a common stem. $\mathrm{Sc} 1$ short, running into the node; $\mathrm{Sc} 2$ rounded, following the nodal margin. $\mathrm{R}$ tribranched, united to $\mathrm{M}$ by one nodal transverse $\mathrm{r}-\mathrm{m}$ vein; $\mathrm{M}$ diverging at the nodal line in $\mathrm{M} 1+2$ and $\mathrm{M} 3+4$, preapically separating into four branches; $\mathrm{Cu}$ diverging at the nodal line, $\mathrm{CuAl}$ fused with $\mathrm{M} 3+4$ over a short distance. $\mathrm{R}$ of the hindwing simple. Metacoxae lacking denticle. Metatibia without spines, apically with two groups of widely separated three spines. Metatibiotarsal formula 3-3/8-7/7; Metatarsus I as long as II + III together. Abdominal tergites VI, VII and VIII bearing on their posterior margin 12 finger-like invaginations corresponding to the canals of tegumentary glands ( 6 on each side), only visible after dissection.

Male genitalia (Figs 24-26): Pygofer symmetrical, bearing a long and lanceolated medio-ventral process, with a strong medio-ventral carina; latero-posterior margin of the pygofer developed dorsally forming a small wide-based triangular process; pygofer developed anteriorly on its ventral side. Gonostyli symmetrical, apically abruptly bent, turning transversally. Periandrium strongly developed with two long acute processes on its right side; the lateral one curved at $360^{\circ}$. Aedeagus tubular, apically wider than basally. Ventral support of the connective strong, anteriorly bent at mid length. Anal segment elongated, symmetrical, surpassing the genitalia in lateral 


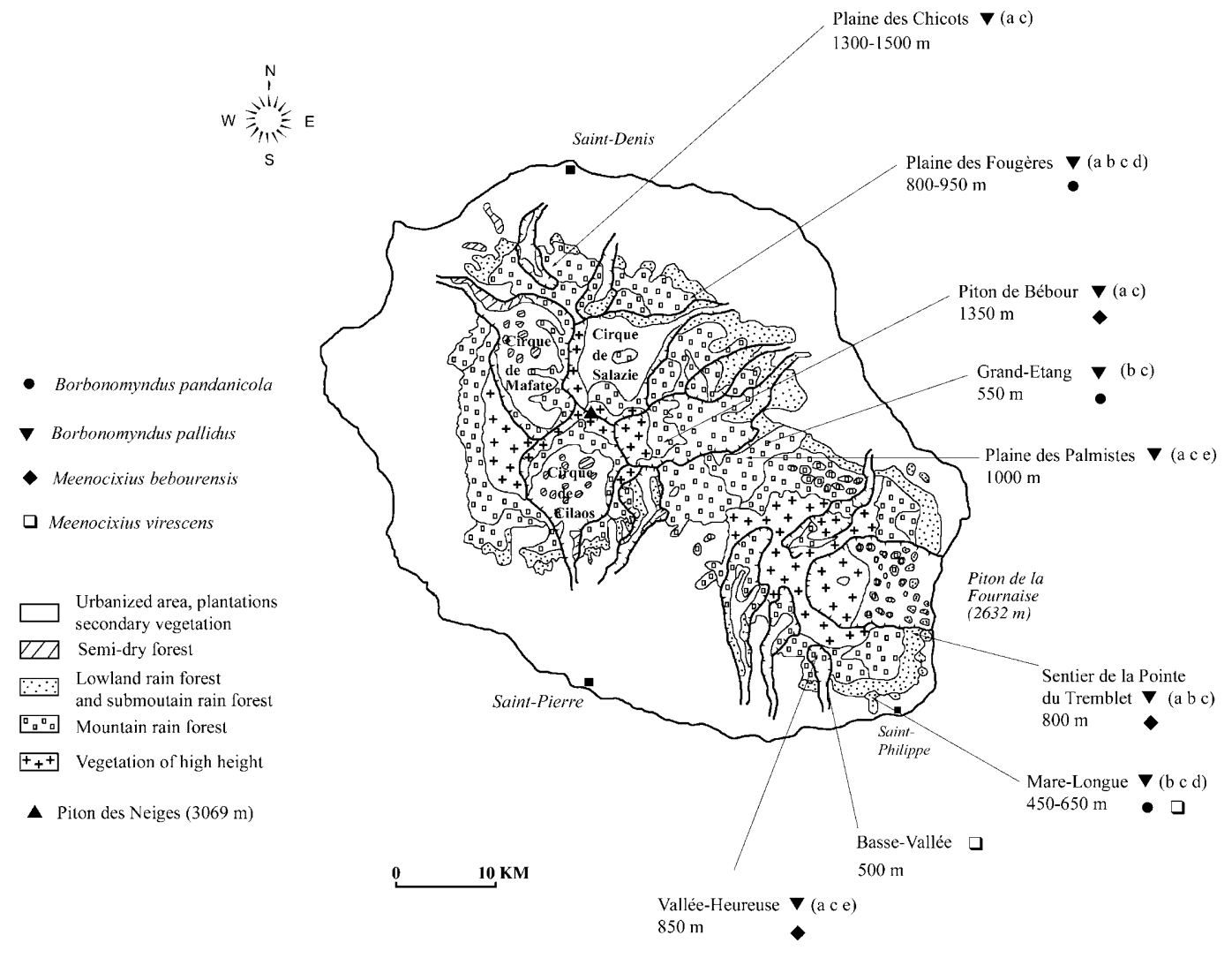

Fig. 22. La Réunion Island, collecting localities.

view; ventral margin dinstinctly longer than the dorsal one. (Fig. 26).

Female genitalia of orthopteroid type (Bourgoin, 1993) with a long and well developed ovipositor. No wax plate. Spermatheca very long, coiled 4-5 times from outside to inside in the same plane but not around itself. Bursa copulatrix bubble-like, totally covered with small tegumentary sculpturations. Ovipositor about $1.5 \mathrm{~mm}$, longer than the anal tube. Gonapophyses IX fully united. Anal tube short. Epiproct strongly developed.

Type species. Meenocixius bebourensis $\mathrm{sp} . \mathrm{n}$.

\section{Meenocixius bebourensis sp. $\mathbf{n}$.}

Very similar to $M$. virescens but general colour more orange. All lines and carinae tinged with orange. Tegminae without transverse veins; with three dark brown spots (Fig. 14), on m-cu, $\mathrm{m} 1+2-\mathrm{m} 3+4$ and $\mathrm{m} 3+4-\mathrm{cu}$, respectively; in one specimen more or less coalescent. Apical spines of tibiae, tarsae and claws blackened at their tips. Ventral side of the abdomen dark brown.

Male genitalia with periandrium ring-like, prolonged by a ventral spine bent upwards and slightly to the right. Lateral to the aedeagus, periandrium with a long spine bent laterad at $360^{\circ}$, sometimes passing below the aedeagus by slightly turning to the left. Gonostyli symmetrical, medially inflated, apically transverse and bilobate (Fig. 24), the internal lobe slightly longer than the lateral one. Anal tube long, its ventral margin in lateral view more than twice as long as the dorsal margin. Epiproct not reaching the posterior margin of the anal tube (Fig. 27).
Measurements. Male (2 ex.), total length: 5.72 and $5.88 \mathrm{~mm}$, tegminae: $4.8-5.2 \mathrm{~mm}$;

Female (1 ex.), total length: $6.35 \mathrm{~mm}$, tegmina: 5.65 $\mathrm{mm}$.

Holotype male: La Réunion, MA 1412, Bébour, 10.XII.1996, on Acanthophonix rubra palms, (M. Attié rec.), deposited in MNHN.

Paratypes. 1 if same data as holotype (deposited in MNHN).

Other material examined. In MNHN: $1 \hat{\delta}, 1$, La Réunion, MA 1656, Sentier de la pointe du Tremblet, I.2000, (M. Attié leg.); in coll. Attié: 10, Bébour, 10.XII.1996, on Acanthophonix rubra, (Ref. MA 1452, M. Attié rec.), 30, idem, (Ref. MA 1452, M. Attié rec.) in coll. Bonfils; 5 specimens sur Acanthphoenix rubra, Vallée-Heureuse, 23.XI.2000 (Ref. MA 1670, Attié rec. used for molecular sequencing).

\section{Meenocixius virescens sp. n. (Fig. 28)}

Smaller than $M$. bebourensis. General colour greenish to yellowish. Pronotum and disk of mesonotum paler. Lateral part of mesonotum somewhat more orange. All carinae concolorous or paler. Tegminae hyaline greenish, with transverse veins. No dark spot on the tegminae. Apical spines of tibiae, tarsae and claws blackened apically.

Male genitalia very similar to that of $M$. bebourensis, but smaller (Figs 25, 26). Periandrium ring-like, prolonged by a ventral spine bent upwards and slightly to the right. Periandrium lateral to the aedeagus on the right side, with a long spine bent at almost $360^{\circ}$. Gonostyli inflated medially, apically transverse and bilobate. Anal 


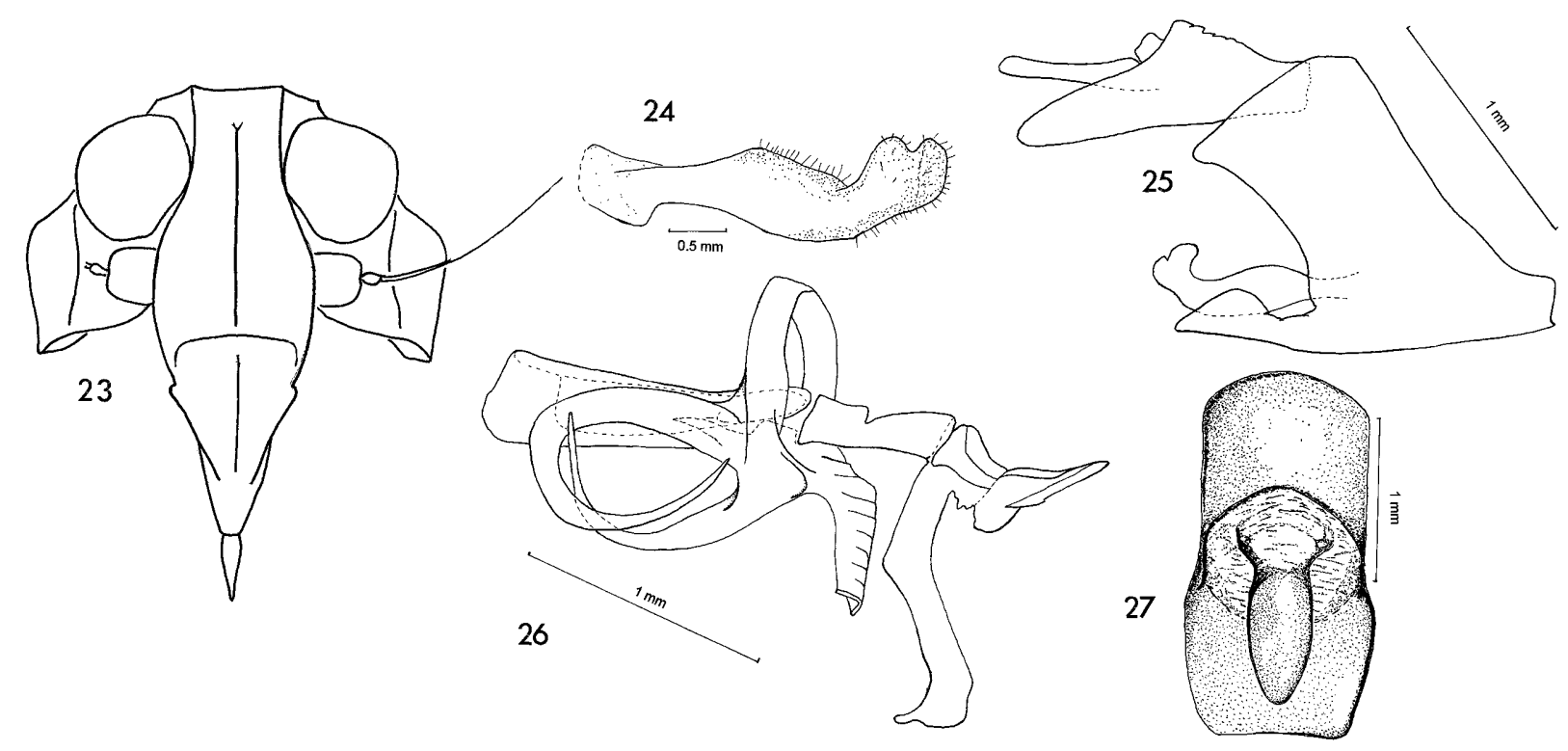

Figs 23-27. Meenocixius gen. n. - M. bebourensis sp. n.: 23 - head capsule, frontal view; 24 - left gonostylus, latero-external view; 27 - anal tube, dorsal view. $M$. virescens sp. n.: 25 - pygofer, anal tube and gonostyli; 26 - male genitalia, dissected, view from right.

tube long, its ventral margin more than twice as long as the dorsal margin in lateral view. Epiproct long, surpassing the posterior margin of the anal tube.

\section{Measurements.}

Male (5 ex.), total length: $4.5-4.86 \mathrm{~mm}$; tegminae: $3.96-4.25 \mathrm{~mm}$.

Female (5 ex.), total length: $4.8-5.1 \mathrm{~mm}$; tegminae: $4.25-4.45 \mathrm{~mm}$.

\section{Material examined.}

Holotype male: Sur Acanthophenix rubra, Basse-Vallée, 3.IV.1999 (Ref. MA 1585, M. Attié rec.); deposited in MNHN.

Paratypes $10 \hat{\delta}, 8 q$ same data as holotype; deposited in MNHN.

Other material studied. $5 \hat{\circ}, 5 \%$, La Réunion, MA 1539 , Basse-Vallée, 4.XII.1997, on palmes of Acanthophonix rubra (M. Attié \& G. Morel rec.); 26ð, 23 q, idem, 4.XII.1997, (Ref MA 1535, M. Attié \& G. Morel rec.); 20, 5 q, idem, 13.I.1998 (Ref. MA 1583, M. Attié rec.); 14ð, 10 , idem, (ref. MA 1585, Attié rec.); 50 , 69, idem, 19.V.1998 (Ref. MA 1669, M. Attié rec.); 1o, 1 ㅇ in copula, idem, 10.IV.1999 (Ref. MA 1586, M. Attié rec.) in coll. Attié.

\section{Notes about Meenocixius}

Morphology. In the genus description, we refer to three anal veins. It is clear, however, that one of these veins - probably the first one - is not a real vein, homologous with a true anal vein. More morphological work is needed to verify this point, which might be important in future research, as the level of fusion of the anal veins may be a character of phylogenetic value

Taxonomy. $M$. virescens looks rather similar to $M$. bebourensis but is distinctly smaller, the general colour is paller and it lacks dark spots on the tegminae. The male genitalia are very similar but also much smaller, and the lateral processes of the periandrium are slender and generally transversally bent. As $M$. virescens lives at lower altitudes and in different habitats to $M$. bebourensis - but on the same host-plant - we describe them as different species. However, when more data becomes available they may be shown to be conspecific.

These two species look very different from other Cixiidae. Because of their very special venation bearing setae, the genus does not fit into the Cixiid classification proposed by Emeljanov (1997). According to his "tentative cladogramme", Meenocixius has a short displacement of the cubital transverse vein joining the wing margin and steeply tectiform forewings. Assuming that Emeljanov's classification is correct, these characters place Meenocixius close to the clade (((Brixidiini+Bennini)+Brixini)+Andini) and could constitute a new tribe. However a complete cladistic analysis will be necessary to verify this statement.

Host-plants and distribution of Meenocixius on La Réunion. The adults of Meenocixius bebourensis $\mathrm{sp} . \mathrm{n}$. and Meenocixius virescens sp. $\mathrm{n}$. live and reproduce on the lower surface of the palms of the red cabbage tree, Acanthophonix rubra (Bory) H. Wendl. This species of Arecaceae (= Palmaceae) is endemic to La Réunion and Mauritius (Moore \& Guého, 1984) and is not very common in natural biotopes. Wild trees are confined to humid forests from low to middle altitudes and have been overexploited for a long time. Meenocixius are to be found in the concave base of the leaflets and also close to the feathery line along the main vein of the palms.

Meenocixius bebourensis was only found in the montane rain forest (between 940 to $1350 \mathrm{~m}$ altitude), which receives an annual rainfall of 4000 to $5000 \mathrm{~mm}$ (Fig. 22). Meenocixius virescens has also been observed on wild cabbage trees and on cultivated seedlings in secondary forest or near the edge of native forest. This species is relatively more common in the region of "Saint-Philippe" (south-east of the island) at altitudes from 50 to $550 \mathrm{~m}$. 


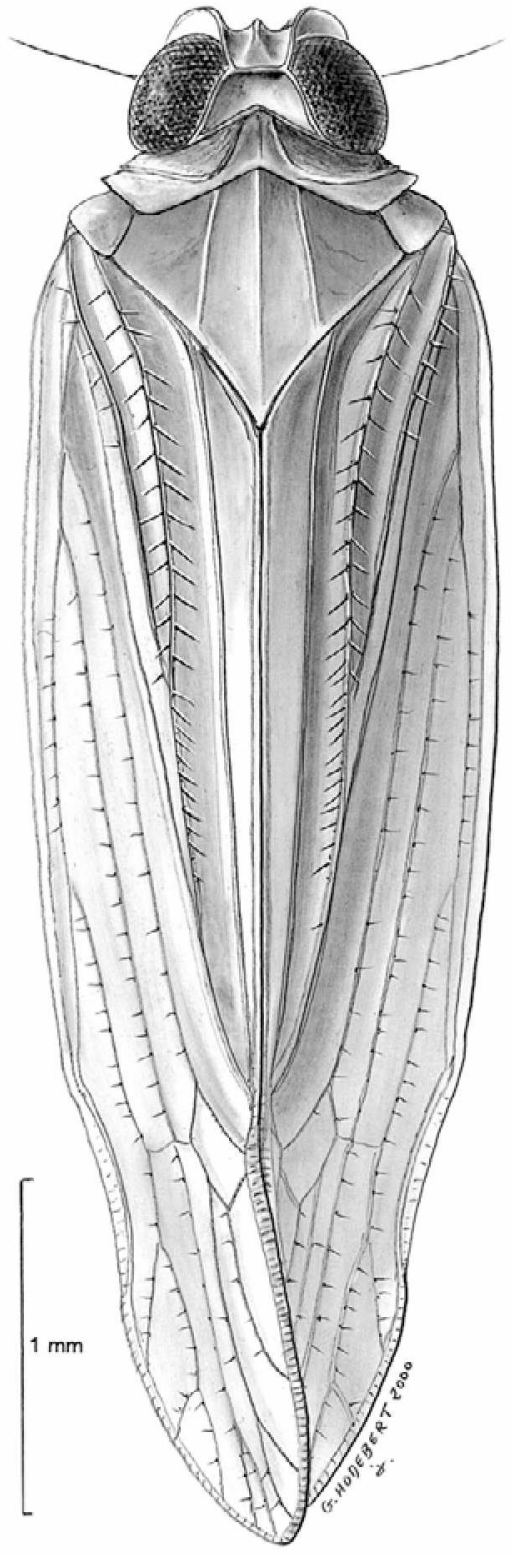

Fig. 28. Meenocixius virescens $\mathrm{sp} . \mathrm{n}$.

This area receives an annual rainfall of 3000 to $4000 \mathrm{~mm}$, depending altitude (Soler, 1997).

\section{THE GENUS OLIARUS IN LA RÉUNION}

The genus Oliarus was erected by Stål (1862) for some species previously described in the genus Cixius Latreille. The type species was designated by Distant (1906) and it is an Oriental species described as Cixius walkeri Stål. Since, almost all cixiids bearing five keels on the mesonotum were included in this genus - 492 species according to Tsaur et al., 1988 - until the work of Emeljanov (1971), who begun to divide the composite genus Oliarus into different genera within a new tribe: Pentastirini Emeljanov, 1971. In 1987, Van Stalle published a review of the African fauna and listed 133 different species belonging to Oliarus. However, Emeljanov (1992) reassigned all of these species to three other genera Eumecurus Emeljanov, 1971, Atonurus Emeljanov, 1992 and Suriola Emeljanov, 1992. Therefore the genus Oliarus sensu Emeljanov, was considered as absent from continental Africa, and restricted to the Eastern Palaearctic, Oriental, Australian and Oceanic regions. Similarly, the Oriental species revised by Van Stalle in 1991, were also assigned to several new genera by Emeljanov 2002. The distribution of the genus Oliarus s.s. is therefore now restricted to the Oriental area (Indo-Malayan).

In La Réunion, however, two species have been described belonging this genus: O. sanctiphilippi Synave, 1960 and O. borbonicus Williams, 1975. Based on the new characters used by both Emeljanov $(1971,1992)$ and Van Stalle $(1986,1987)$ the two species are congeneric and share several key characters: vertex converging anteriorly in an acute angle; supraocular field narrower than anteocular field; postclypeus reaching the level of upper margin of antennae; clypeus mediocarinated; fork of median carina of frons extending approximatively $1 / 4$ of the length of the frons; costal vein setiferous, but without granules; metatibia with two close spines basally (the first often very reduced) and two more developed spines on the first $2 / 3$ of the tibia; metatibiotarsal formula: $1+2+3 / 7 / 5$; subapical setae absent on apical teeth of segments of the hind tibia. Anal segment of female large, almost as wide as the wax plate, diamond-shaped. Male genitalia symmetrical, relatively simple with an elongate periandrium without a basal process, and two long spines apically.

Using the key for African species, these characters lead to the subtribe Oliarina Emeljanov, 1971, and to the couplet 6-7 in Emeljanov's key (1971). It differs from Eumecurus in its metatibiotarsal formula $(6 / 7 / 5$ versus 6/7/7 in Eumecurus), the absence of the asymmetrical projection of the anal tube, the clypeus reaching the upper level of antennae and having a short ovipositor (length not surpassing the length of the wax plate). It differs from Pseudolarius in the short fork in the mediofrontal carina and the presence of the distal segment of the aedeagus. Van Stalle (1987) also noted that the fauna of Madagascar and adjacent areas lack species of Pentastirine in common with the African continent. Indeed, these two species differ both from species of Atonurus and Suriola in having a symmetrical pygofer with blunt lobes and by the rather simple condition of the male genitalia with an elongate tube-like periandrium without any basal supernumerary process (see Williams, 1975b, figs 1 and 2). According to Van Stalle (1986) the diamond-shaped female anal segment is characteristic of the genus Peartolus Van Stalle, 1986 and of the "Oliarus lacon group", (now Suriola, Emeljanov, 1992). However again, the male genitalia and the greater development of the female anal segment exclude these species from these two taxa.

Following Van Stalle's key (1991) to Oriental pentastirini, these characters lead to Oliarus, couplet III, and using Emeljanov's key (2002), the gonostyli with an apical laterodorsal tooth lead to the genus Indolipa Emel- 


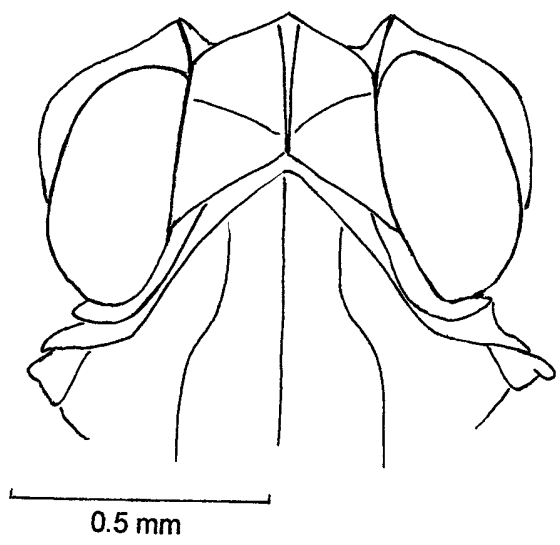

Fig. 29. Achaebana insularis (Muir, 1924) - head capsule, frontal view.

janov, 2002, a genus found in India and Malaysia. However, a more comprehensive study of the other Oliarus species described from Madagascaris needed before placing these species into this genus.

\section{THE GENUS BRIXIA IN LA RÉUNION}

According to Williams (1975b), intraspecific variation within the Reunion species $B$. belouvensis has no equivalent in Mauritius and could be considered as evidence of speciation in progress. But subspecies are local populations of a species inhabiting a geographic subdivision of the rang of a species. In describing subspecies, a geographic factor is therefore needed. However, the different subspecies described for Brixia belouvensis are only distinguished by the pigmentation of their tegmina (Williams \& Williams, 1988) and lack any geographic criteria. Without taxonomic standing, the synonymy of the four subspecies is therefore proposed and as in B. pallidus, forms are only recognized here to facilitate field research.

Brixia belouvensis Synave, 1960 (1959: 142)

B. belouvensis aurata Synave, 1959: 145, syn. n.

B. belouvensis bipunctata Synave, 1959: 143, syn. n.

B. belouvensis tristis Williams, 1975: 678, syn. n.

form belouvensis
form aurata
form bipunctata
form tristis

\section{KEY TO THE GENERA AND SPECIES OF CIXIIDAE FROM LA RÉUNION}

A new key to genera and species of Cixiidae from $\mathrm{La}$ Réunion is provided, modified from the previous key of Williams (1975).

1. Cavernicolous species $\ldots \ldots \ldots \ldots \ldots \ldots \ldots \ldots$ ............. Brixia sp. n. (Hoch et al., in prep.)

Epigeic species .................... 2

2 Mesonotum with 5 carinae ....... Oliarus Stål, 1862, 3

- Mesonotum with 3 carinae ................ 4

3 In male, gonostyli apically quadrangular, ventrolateral margins of anal tube apically joined, tegminae with apical infuscation .......... O. sanctiphilippi Synave, 1960
In male, gonostyli rounded dorso-apically, ventrolateral margins of anal tube apically clearly separated, tegminae hyaline ............ O. borbonicus Williams, 1975

4 Postclypeus without median carina Borbonomyndus gen. n. .................. 5

Postclypeus with a median carina $\ldots \ldots \ldots \ldots \ldots 6$

5 Frons uniform brown; small species: less than $4.8 \mathrm{~mm} \ldots$ B. pallidus (Synave, 1960)

- Frons dark brown, a pale spot between the eyes; large species, more than $5.2 \mathrm{~mm}$...... B. pandanicola sp. $\mathrm{n}$.

6 Vertex in lateral view almost as long as the diameter of the compound eye ..... Alsegeoides paludaris Williams, 1975

- Vertex in lateral view no more as half long as the diameter of the compound eye $\ldots \ldots \ldots \ldots \ldots \ldots \ldots \ldots$

7 Tegminae with $\mathrm{Sc}, \mathrm{R}$ and $\mathrm{M}$ with a common stem $\ldots \ldots 8$

- Tegminae with $\mathrm{M}$ separate basally from $\mathrm{Sc}+\mathrm{R} \ldots \ldots$. .......... Achaemenes quinquespinosus Synave, 1960

8 Frons with a median carina ....... Meenocixius gen. n., 9

- Frons without a median carina .... Brixia Stål, 1856, 10

9 Tegminae with three darks spots sometimes merging into each other .................. bebourensis $\mathrm{sp} . \mathrm{n}$.

- Tegminae greenish uniform, no dark spot $\ldots \ldots \ldots \ldots \ldots$ ........................... virescens sp. n.

10 Apical dorsal process of the gonostyli in lateral view with diverging margins $\ldots \ldots \ldots \ldots \ldots \ldots \ldots \ldots$ Apical dorsal process of the gonostyli with parallel or con-

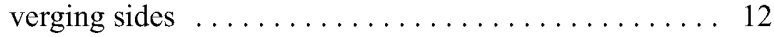

11 Apical dorsal process of gonostyli longer than wide ..... B. insularis Synave, 1960 Apical dorsal process of gonostyli as wide as long ...... ................. B. lalouetti Synave, 1960

12 Apical dorsal process of gonostyli longer than wide in lateral view, with parallel margins

B. belouvensis Synave, 1960 - Apical dorsal process of gonostyli wider than height in lateral view, with converging margins $\ldots \ldots \ldots \ldots \ldots \ldots$

B. costalis Synave, 1960

\section{RODRIGUES: THE $C U B A N A$ PROBLEM}

The genus Cubana is almost exclusively confined to the Carribbean Islands and the presence of this West Indies genus in the Mascarenes area was questionable. Moreover, the species C. insularis Muir, 1925, was collected only once (a male) and only provisionally placed into this genus (Muir, 1925).

As expected by the venation of the tegmina only superficially similar to Cubana, a reexamination of this specimen, stored in the BMNH, revealed that it is not congeneric with Cubana, but is much closer to Achaemenes. Moreover, the very distinctive shape of the vertex, with an incomplete transverse ridge, angularly shaped oposite the anterior margin of the vertex, argue for placing this taxon in a distinctive taxonomic unit, perhaps endemic to Rodrigues. However a taxonomic revision and a phylogenetic analysis of the Achaemenes species of the area is needed to confirm the new genus proposed here.

\section{Achaebana gen. n.}

Type species. Cubana insularis Muir, 1924

Distribution. Endemic to Rodrigues Island

Included species. Achaebana insularis (Muir, 1924)

Vertex hexagonal (Fig. 29), its width medially equals its length anteriorally; disk hollowed, a middle carina not 
reaching the posterior margin. Anterior and posterior margins parallel, the posterior one slightly elevated. Tranverse carina incomplete, vanishing, almost reaching the middle carina, not straight but angularly shaped oposite the anterior margin. Frons, postclypeus and clypeus medially carinated. Median ocellus absent. Frons at the antennal level almost twice as large as dorsally. Clypeofrontal margin dorsally arched. Lateral ocelli large, widely separated from the eyes; antennal base facing anterodorsally; pedicellus as long as wide, in frontal view almost hidden by the wide development of the laterofrontal foliated carinae at this level. Pronotum with disk almost hidden by the head capsule; posterior margin strongly angled anteriad, lateral margins rounded, meeting the posterior margin behind the eyes, then turning anteriad but not reaching the antero-ventral margin. Mesonotum tri-carinated, with lateral carinae slightly diverging in their anterior section, then widely diverging before converging posteriorly. Tegminae with $\mathrm{M}$ starting from the basal cell, five branches, M3+4 diverging at the postnodal line; Sc+R forking before the level of fork of CuA. Metatibiotarsal formula: $6 / 8 / 5$.

The unique holotype male deposited in BMNH has not been dissected.

Unfortunately as already mentioned by Muir in 1925 , the native vegetation of Rodrigues island has been "destroyed to a terrible extent" and the chance of collecting this species again is very low as it is probably extinct.

\section{ENDEMISM AT THE GENERIC AND SPECIFIC LEVELS OF CIXIIDAE IN THE MASCARENES AND MADAGASCAR}

The Cixiidae of La Réunion currently consist of 13 species (one species under description, Hoch et al., in preparation) belonging to six genera: Achaemenes, Brixia, Oliarus, Aselgeoides, Borbonomyndus and Meenocixius. Although the inventory of planthoppers of the Mascarenes, and particularly of Madagascar, still remains to be supplemented, we can state a priori that the generic diversity of Cixiidae is greater on La Réunion than Mauritius (Achaemenes, Brixia and Oliarus) and Rodrigues (Brixia and Achaebana). One explanation is that the genera found on these volcanic islands probably originated from Malagasy species. Seven Cixiid genera have been reported from Madagascar (Synave, 1956, 1965): Achaemenes, Oliarus, Brixia, Aselgeoides plus three Malagasy endemics: Eumyndus, Nesomyndus and Typhlobrixia Synave, 1952. The higher generic diversity of Cixiidae on La Réunion could be explained by its closer proximity to the large island. Indeed, La Réunion is about $700 \mathrm{~km}$ from Madagascar while Mauritius and Rodrigues are respectively more than $850 \mathrm{~km}$ and $1250 \mathrm{~km}$ from Madagascar. However such a comparison needs to be balanced by comparing the Mascarenes and Madagascar faunas more generally. Furthermore, endemism and species diversity should be taken into account.

Table 2 shows a basic common stock of three genera: the African genus Achaemenes, the Malagasian Brixia, and the genus Oliarus, absent from continental Africa but reported from Mascarenes and Madagascar and whose species probably belongs to a new generic taxa. In addition, the genus Aselgeoides, absent from Mauritius and Rodrigues, also probably belongs to this basic stock. Indeed, one species is described by Fennah (1969) from New Caledonia, and also Synave (1956) mentions an undetermined female from Upemba national park (Zaire) in Africa. Even if such a distribution appears odd, these data indicate a broader distribution than only the Seychelles area. All others genera seems endemic to their island as on La Réunion, Meenocixius which clearly looks different from any other Cixiid genera.

But of course, at the supraspecific level, endemism is a difficult task to establish because phylogenetic studies are lacking and genus recognition is taxonomist dependent. In La Reunion, the Cixiid genera Eumyndus and Borbonomyndus for instance are rather close genera (but not necessarily sister taxa), and should have been considered congeneric by others, while they are well defined by their respective autapomorphies.

This is true also for Madagascar, and further collections and taxonomic revisions of the Cixiid fauna will probably increase the number of endemic genera, as on La Réunion. The species Achaemenes andringitensis Synave, 1965 , is one example as this species clearly does not belong to Achaemenes and will have to be reassigned to a new genus. On the other hand, Typhlobrixia for instance, which seems to differ from Brixia only in a few modifications attributable to its subterranean way of life (Synave, 1953; 1956), could be included into the Brixia clade even if it is well separated from this genus by its wing venation (in particular the absence of the common stem $\mathrm{M}+\mathrm{Sc}+\mathrm{R}$ ).

In other words, comparison of not necessarily comparable generic taxa (only phylogenetically sister taxa should be) is meaningless and the only report on the Mascarenes Cixiids should recognise that the distribution of the cosmopolitan genera decreases with the distance from Madagascar and should not focus on the endemic genera. Dispersal appears to be a major factor determining the origin of the faunal diversity of these recent islands. However, the presence of some derived endemic genera, like Meenocixius, provide evidence of subsequent speciation. But without phylogenetic data, most of these conclusion remain speculative.

At the specific level, the analysis of distribution patterns paradoxically reveals a higher specific diversity on Mauritius, which is more distant and much more strongly influenced by man (Williams \& Williams, 1988). This island has almost three times as many species as La Réunion but half as many genera (Table 2). Moreover, Mauritius seems more homogenous in terms of habitat diversity than La Réunion, as it is smaller $\left(1865 \mathrm{~km}^{2}\right.$ versus $2512 \mathrm{~km}^{2}$ ) and has a lower altitude $(826 \mathrm{~m}$ versus $3069 \mathrm{~m}$ ). This does not favour speciation as a factor of the origin of the faunal diversity.

Of course, the older age of Mauritius ( 8 million years) compared to La Réunion (3 million years) may account for the higher species diversity. But how does one explain the absence of any endemic genus? One answer would be 
TABLE. 2. Distribution and numbers of species (sp) of Cixiid genera (gr) on Madagascar and the Mascarenes Islands, with their geological age, in parenthesis.

\begin{tabular}{|c|c|c|c|c|c|}
\hline \multirow{2}{*}{ Genera } & \multirow{2}{*}{ Madagascar } & \multicolumn{3}{|c|}{ Mascarenes } & \multirow{2}{*}{ Distribution } \\
\hline & & $\begin{array}{l}\text { La Réunion } \\
{[3 \mathrm{MY}]}\end{array}$ & $\begin{array}{l}\text { Mauritius } \\
{[8 \mathrm{MY}]}\end{array}$ & $\begin{array}{l}\text { Rodrigues } \\
{[1,5 \mathrm{MY}]}\end{array}$ & \\
\hline Brixia & 36 & $4+1$ & 27 & 3 & Madagascar \\
\hline Achaemenes & 12 & 1 & 3 & - & Africa \\
\hline \multirow[t]{2}{*}{ Oliarus } & 6 & 2 & 3 & - & $\begin{array}{l}\text { Palaearctic, Oriental, } \\
\text { and Australian regions }\end{array}$ \\
\hline & \multicolumn{4}{|c|}{ (species probably non congeneric) } & \\
\hline Aselgeoides & 2 & 1 & - & - & Seychelles, Africa, New Caledonia \\
\hline Typhlobrixia & 1 & - & - & - & Madagascar, endemic \\
\hline Eumyndus & 3 & - & - & - & Madagascar, endemic \\
\hline E. perinetensis & 1 & - & - & - & Madagascar, endemic \\
\hline Nesomyndus & 1 & - & - & - & Madagascar, endemic \\
\hline Borbonomyndus & - & 2 & - & - & La Réunion, endemic \\
\hline Meenocixius & - & 2 & - & - & La Réunion, endemic \\
\hline Achaebana & - & - & - & 1 & Rodrigues, endemic \\
\hline Total & $8 \mathrm{gr} / 62 \mathrm{sp}$ & $6 \mathrm{gr} / 13 \mathrm{sp}$ & $3 \mathrm{gr} / 33 \mathrm{sp}$ & $2 \mathrm{gr} / 4 \mathrm{sp}$ & \\
\hline Notes & $\begin{array}{c}\mathrm{Nb} \text { genera } \\
\text { underestimed }\end{array}$ & $\begin{array}{l}1 \text { Brixia sp. in } \\
\text { prep. }\end{array}$ & & & \\
\hline
\end{tabular}

that the origin of the Cixiid fauna of Mauritius is due to multiple and repetitive successful dispersal events, most probably evolving without speciation. Conversely, on La Réunion, several dispersal events were followed by evolution of new species groups and the establishment of endemic genera. A phylogeny of these taxa would test this hypothesis. It is interesting to note that in the last case, a consequence of the successful speciation would render all the dispersing Malagasian genera paraphyletic.

In conclusion, among the Fulgoromorpha the Cixiid family on La Réunion is the richest in endemic species (Attié, 1999). Indeed 11 of the 13 species are endemic $(85 \%)$, and moreover they are associated with native plants. Likewise, on Mauritius 31 of the 33 species are endemic (94\%) and found on native vegetation (Williams, 1975a). However, the species diversity on the two islands has probably a different origin. Compared to La Réunion, the greater distance from Mauritius to Madagascar is balanced by its older geological age, and it has probably received and retained more colonists. Furthermore, the lower degree of generic endemism on Mauritius might reflect reduced speciation because it is apparently more homogenous.

New studies are now needed to show how much of this biodiversity can be explained in terms of dispersal followed by island speciation, as can be assumed for the endemic genera of La Reunion Moreover, the overall significance of colonization events has to be evaluated, particularly on Mauritius. Finally more attention should be paid to the influence of host plant diversity, which obviously had a great impact on the speciation of these sap sucking insects.

ACKNOWLEDGEMENTS. We should like to thank Professor G. Morel (University of La Réunion) for his help in field research and for collecting Borbonomyndus. We also thank Prof.
A. Emeljanov and J. R. Williams for helpful comments, M. Fouillaud and reviewers for reading the manuscript, and $\mathrm{M}$. Webb, BMNH curator, for the loan of Muir's type. The Meenocixius habitus was drawn by G. Hodebert (MNHN). Photographs were taken by A. Franck (CIRAD). This study received financial support from the Regional Council of La Réunion.

\section{REFERENCES}

Aтті́ M. 1999: Étude sur l'Entomofaune associée à la flore indigène de l'île de La Réunion. Thèse de l'Université de La Réunion, $346 \mathrm{p}$.

Attí́ M., Bonfils J. \& Quilici S. 1998: Hémiptères Auchénorrhynques nouveaux pour la faune de l'île de La Réunion. Bull. Soc. Entomol. Fr. 103: 255-262.

Bonfils J., Quilici S. \& ReYNaud B. 1994: Les Hémiptères Auchénorrhynques de l'Ile de la Réunion. Bull. Soc. Entomol. Fr. 99: 227-240.

Bourgorn T. 1993: Female genitalia in Hemiptera Fulgoromorpha, morphological and phylogenetical data. Ann. Soc. Entomol. Fr. (N.S.), 29: 225-244.

Distant W.L. 1906: The fauna of British India, including Ceylon and Burma. Edt. C.T. Bingham, Rhynchota, 3: 503 p.

Emeljanov A.F. 1971: New genera of leafhoppers of the families Cixiidae and Issidae (Homoptera: Auchenorrhyncha) in the USSR. Entomol. Obozr., 50: 619-627.

EMelJanov A.F. 1992: Planthoppers of the family Cixiidae from vicinity of Ambo, Ethiopia (Homoptera: Cicadina). Zoosyste. Rossica 1: 20-36.

Emeluanov A.F. 1997: The Ways of Developing Classification and Reconstructing Phylogeny in the Cixiidae. Program \& Abstract book, 9th International Auchenorrhyncha Congress, 17-21 February 1997, Sydney, Australia, pp. 38-39.

Fennah R.G. 1969: Fulgoroidea (Homoptera) from New Caledonia and the Loyalty Islands. Pac. Insects Monogr. 21, $1-116$.

MoOre H.E. \& GúEHo L.J. 1984: Flore des Mascareignes, La Réunion, Maurice, Rodrigues. Palmiers. MSIRI, Mauritius, 
ORSTOM, Paris, France \& Royal Botanic Gardens, Kew, UK. $189,34 \mathrm{p}$.

Murr F. 1925: On some Fulgorids [Hemiptera-Homoptera] from the Island of Rodriguez. Trans. Entomol. Soc. Lond. [1924], parts III, IV: 463-474

Soler O. 1997: Atlas Climatologique de La Réunion. MétéoFrance, $79 \mathrm{p}$.

STÅL C. 1862: Novae vel minus cognitae Homopterorum formae et species. Berliner. Entomol. Ztg. 6: 303-315.

SYNAVE H. 1953: Un cixiide troglobie découvert dans les galeries souterraines du système de Namoroka (Hemiptera Homoptera). Nat Malgache V 2: 175-179.

Srnave H. 1956: Les Cixiidae de Madagascar (Hemiptera Homoptera). Mém. Institut Madag. ser. E. 7: 167-196.

SynAve H. 1960: Cixiidae de La Réunion (HomopteraFulgoroidea). Nat. Malgache [1959], 11: 133-145.

SrNAVE H. 1961: Quelques espèces nouvelles ou peu communes de l'ile Maurice (Homoptera, Fulgoroidea). Bull. Inst. R. Sc. Nat. Belg. 37: 1-20.

SynAve H. 1965: Contribution à la connaissance des Cixiidae de Madagascar, Maurice et de La Réunion. (Homoptera: Fulgoroidae). Bull. Inst. R. Sc. Nat. Belg. 41: 1-57.

Tsaur S.C., Hsu T.C. \& J.V. STalle 1988: Cixiidae of Taiwan, Part (1) Pentastirini. J. Taiwan Mus., 41: 35-74.
Van Stalle J. 1986: Revision of Afrotropical Pentastirini (Homoptera, Cixiidae) IV: description of Pearolus gen. nov., Dorialus gen. nov., Narravertus gen. nov., Kibofascius gen. nov., Afroreptalus gen. nov. and Pseudoliarus hudeibensis $\mathrm{n}$. sp., with notes on phylogeny and systematics. Mededelingen van de Koninklijke Academie voor Wetenschappen, letteren en schone Kunsten van België, Klasse des Wetenschappen, Jaargang 48: 100-129.

Van Stalle J. 1987: Revision of Afrotropical Pentastirini (Homoptera: Cixiidae) V: the genus Oliarus Stål, 1862. Musée Royal de l'Afrique Centrale, Tervuren, Belgique. Zoologische Wetenschappen 252: $173 \mathrm{p}$.

Williams J.R. \& Williams D.J. 1988: Homoptera of the Mascarene Islands - an annotated catalogue. Entomology Memoir Department of Agriculture and Water Supply. Republic of South Africa, 72: $98 \mathrm{p}$.

Williams J.R. 1975a: Cixiidae (Fulgoroidea: Homoptera) of Mauritius. J. Nat. Hist. 9: 169-204.

Williams J.R. 1975b: Cixiidae (Fulgoroidea: Homoptera) from Réunion Island. J. Nat. Hist. 9: 669-680.

Williams J.R. 1983: Description of Mascarene Fulgoroidea (Homoptera). J. Entomol. Soc. Sth. Afr. 46: 1-7.

Received July 30, 2001; revised April 25, 2002; accepted June 24, 2002 